\title{
Spatializing Social Change: Artisanal and Small-Scale Gold Mining in Upper Guinea
}

\author{
Anna Dessertine
}

On a warm evening in June 2011, Madou was drinking tea and eating beans at a bar in a mining camp near Siguiri in Guinea. Several other miners were sitting on wooden benches at small tables covered with colored plastic tablecloths. A television was showing a video clip of Céline Dion, and while some men were discussing her looks, others were merely staring at the ground, apparently thinking or waiting for time to pass. Suddenly, the bright headlights of four motorcycles illuminated the bar before quickly disappearing again. Less than a minute later, the motorcycles came back, this time from the other direction. This parade lasted more than twenty minutes with the bikers going back and forth, interrupting the miners' conversations and reveries in the cafe bar. After a while, I asked an elderly miner why they were doing this. He responded:

\footnotetext{
A. Dessertine $(\varangle)$

Institut de Recherche pour le Développement (IRD), UMR 215 Prodig, Marseille, France e-mail: anna.dessertine@ird.fr

Institut National d'Aménagement et d'Urbanisme, Rabat, Morocco 
- Theyre burning gas to show that they have money.

- I don't really understand, I said.

- They're burning gas for nothing. It's just to show off. By doing that, they're showing that they don't care about money, that they have enough to waste.

- Do miners often do that?

- No. It's only the young miners. Times have changed: now it's all about cultivating image. They don't care about others, they don't care about their family, they don't care about anything. They watch video clips of naked women and think they're big guys while they actually do nothing for their living.

- Yet they work in the gold mines...

- Yeah, but for what? They're empty. Nothing counts nowadays...

How can an apparently insignificant situation in Guinea where miners are listening to the famous Canadian singer Céline Dion while young men are showing off by burning gas help us understand social change? In this chapter I answer this question from two different perspectives.

The first is methodological, and considers the essential role of ordinary actions, or what Max Gluckman calls "social situations," in an anthropological approach. In his pioneer article, published in two parts (1940a, b), he opens his analysis of social organization and social change in Zululand with a dense description of the local inauguration of a bridge. Based on this event, he shows how the analysis of social organization and its structure requires attention to apparently insignificant details, and how this is an indicator of broad processes of transformation.

Following Gluckman, I pay attention to what may be seen as minor or insignificant actions and show how they are charged with local meanings about social life, and how the different interpretations of these actions are crucial to understanding social change. More than mere illustrations, the everyday actions, reactions, and conversations described in this chapter gives insights into broader issues at stake for the miners. As such, they not only offer glimpses into the lives of miners but also allow for certain generalizations about change. Potentially conflictual issues crystallize through daily situations, such as diverging conceptions of modernity and tradition, access to diverse consumption practices, gender expectations, and intergenerational conflicts. By analyzing these 
issues, I throw light on the empirical complexity of what may be called social change in an artisanal gold and small-scale mining context. ${ }^{1}$

The second perspective is theoretical, and concerns the issue of space. Spaces are analyzed here in their complex interconnections (Ferguson and Gupta 1992), and not as a neutral grid to locate people, societies, countries, or cultures as in a map. I focus on mining spaces and see them as shaping an in-between setting implying new modes of relations which partly rely on those deployed in rural areas but also differ from village life in many aspects. I insist on the necessity of spatializing social change by showing how some spaces can be considered transformative because of their in-betweenness. Or, to put it differently, instead of analyzing social change only in relation to time and risking a linear analysis restoring a before and an after, I consider mining spaces as comparable to "hotspots of transition." These, Jörg Dürrschmidt and Taylor (2007) argue, can be defined as "gravitational centers of change" where the complexity of change can be observed most vividly. What makes these hotspots of transition special is their liminal character, a notion of in-betweenness that I find particularly useful in describing the mobility of artisanal gold miners in Guinea. This chapter explores some of the (inter)actions that emerge from this great mobility and the ways it shapes the artisanal and small-scale gold mining spaces.

I consider that social change emerges at the micro-level through observable action as a result of specific spatio-temporal conditions. I assume: (a) that people may experience change when they feel a gap between the ordinary meaning of an action and the meaning that the action acquires in a new context, and (b) that this gap emerges in particular in so-called liminal spaces that are defined by their own temporality and ambiguity related to their in-betweenness across social settings of expectation (Dürrschmidt and Taylor 2007). Liminality is not merely considered here as dissociation from an ordinary context but also as

\footnotetext{
${ }^{1}$ The question of social change in mining contexts has already been investigated by the School of Manchester, mainly inspired by Gluckman's work. See for example Clyde J. Mitchell and Arnold L. Epstein's studies of the Zambian Copperbelt, focusing on prosperity dreams which the boom of the copper market and the formation of mining cities triggered among the population (dreams we can also find, as we will see, in artisanal mining camps in Guinea) and more broadly, on the flexibility with which the population successfully adapted to the new urban context Epstein (1967), regarding marriage for instance (see Mitchell 1961).
} 
generative of change. I look in particular at specific liminality in artisanal and small-scale gold mines in Guinea. By relying on daily stories and micro-actions, I show that the liminality of these spaces is closely linked to (a) their ephemerality, due to the great mobility of artisanal miners induced by new technologies and political developments; and (b) a cultural economy in which new consumption practices transpose an experience of the "global" and the "modern" at the local level.

This chapter is based on a twenty-month period of fieldwork in 20112019 in a rural region in Guinea, during which I spent approximately a year in a Mande village, Guirilan, and six months in different mining camps in the Bouré area, historically known for its gold since the ninth century (Niane and Ki-Zerbo 1991), and near Mandiana. ${ }^{2}$ These areas in Upper Guinea have seen a sharp increase in artisanal gold exploitation since the 2000s, partly due to rises in the price of gold between 2008 and 2012. Artisanal and small-scale gold mining in the region is historically a seasonal activity, with most miners working in the mines during the dry season (November-April) and returning home for the rainy season (May-October) to engage in farming. A third of Guirilan's inhabitants, with men and women in almost equal numbers, were mining gold in 2011. ${ }^{3}$ At the end of that year the introduction of metal detectors led to even more mobility, as miners could prospect for gold on larger areas and would even sometimes sleep outside of the camps. This new mobility involves regular movement between the mining sites and between the village. It has also contributed to the erection of temporary markets and camps, where people meet, stay together for a while, and spend the money they have earned from their mining. As I show, the liminality of mining camps can only be understood in relation to these new forms of mobility and consumption. The situation further evolved around 2015 because of the efforts of local authorities to secure the claims of industrial mining companies to prospect certain areas on an exclusive basis. However, I come back to these last changes later on, after discussing the 2011-2015 situation.

\footnotetext{
${ }^{2}$ During the fieldwork I used a variety of data collection techniques. In addition to participant observation, I conducted two censuses in Guirilan (one during the dry season and another during the rainy season, to estimate seasonal mining mobility) and interviewed 81 young male miners.
}

${ }^{3}$ This estimation is based on two censuses conducted in March and July 2011. 


\section{Mines as Liminal Spaces}

One of the characteristics of mining camps is that they gather people of different origins during short periods. In Upper Guinea, the camps are as ephemeral as the exploitation of the mining fields surrounding them. Some miners stay for a few days, others for months. The duration of these camps is extremely variable and their composition constantly changes. As mentioned in the introduction, I see these mining camps as "hotspots of transition" for two reasons: they can be analyzed as liminal spaces, and they create situations of social or cultural dissonance by bringing diverging interpretations of meaning and perceptions of the social reality into contact with each other (Dürrschmidt and Taylor 2007). I focus here on the former, and question liminality in practice.

Arnold Van Gennep (1909 [1981]) was the first anthropologist to use the notion of liminality in his theory about rites of passage, which he analyzed as moments that mark personal or collective changes of identity. He distinguishes three distinct phases: separation, when the individual or group is distanced from their former identities; aggregation, when the individual or group is readmitted to the society with a new status; and liminality, a moment between the two. The liminal phase is presented as the moment of change, an ambiguous in-between moment when a new identity replaces previous modes of identification. This moment generally occurs in special spaces that are seen as inherently out of the ordinary: a sacred wood, for instance. This process of moving from ordinary space to extra-ordinary space makes the change of status or identity possible.

To some authors, liminality is not only associated with the ritual context, and can be experimented with in other, mostly urban areas: "Our everyday experiences of the global city reflects the liminality of its form: complex patterns of inclusion and exclusion; belonging and not-belonging; rootedness and up-rootedness; and engagement and non-engagement" (Dürrschmidt and Taylor 2007, 3). Dürrschmidt and Taylor argue that liminality is one of the major characteristics of contemporary society (ibid., 159). It is no longer presented as the ideal changing moment in a more general process, but as a specific frame or condition of 
the global world, implying ambiguity and the multiple options that it offers.

One could bring this understanding of liminality closer to Victor Turner's (1974) notion of "liminoïd." However, Turner's analysis relies on a distinction between tribal and agrarian societies and more individualistic ones, with liminality developing in the first type of society and the second being predominantly liminoï. Yet as I show below, this distinction makes little sense in artisanal and small-scale mining spaces, which emerge in what could be considered at first sight a rather rural and agrarian society which at the same time allows the emergence of unique and individualistic behaviors, confirming the in-betweenness of artisanal and small-scale mining spaces even more clearly. Hence liminality is not seen here as linked to a certain type of society but as a frame specific to the global world, with which mining spaces are interconnected. The following explores the first constituent of this frame: the ephemeral character of mines due to the unsustainable nature of gold exploitation and the miner mobility that this implies. I show how ephemeral temporality allows the rise of actions ordinarily forbidden in rural areas, starting with an anecdote concerning two women.

\section{Coffee and Cigarettes: Challenging Gendered Expectations}

In 2011, I spent two months in mining camps near Mandiana, a town about 60 miles east of Kankan. One of the camps was called Faralako and comprised approximately two thousand people, including around 20 inhabitants of Guirilan who had built their huts side by side and were sharing domestic activities such as cooking and cleaning. There were men and women, spouses and children, young and old people in the camp. Every morning, except on Sundays and Mondays, they would go to the field in working groups of four to six men and women to dig pits and lift out bags of gravel. The women stood and washed the gravel in containers in hope of finding gold. ${ }^{4}$ At night, most of the women stayed in their huts to cook and

\footnotetext{
${ }^{4}$ For more information about the organization of work in artisanal and small-scale gold mining in this region, see Dessertine (2016a) and Bolay (2016) on Guinea, and Panella (2007) on
} 
clean, while the men often sat together in a bar. However, one of the women, Mimi, also liked to go to the bar to drink strong black coffee and smoke. Once a man from Guirilan told me: "She behaves like a man. She walks fast, she drinks coffee, sometimes with no sugar. She's strong, you know! She's older than us, and she was the first woman in the village to work in the mines. Before mining for gold, she looked for diamonds in Forested Guinea."

One evening in May 2011, Mimi came back from a bar called At the Big Boss. She seemed angry. She was with a young woman from a village near Guirilan who had come to Faralako with others from the same village. While they were chatting in the bar a man walking by had spat on the ground near them while looking at the young woman. When Mimi asked her who he was, the young woman told her that they had met once before and he was angry with her for refusing his explicit advances. A man who overheard the story jumped in and said: "She's a liar. I'm sure she had intercourse with the man. She's always walking, God knows where she's going. Maybe she even stole his money - girls are like that nowadays. That's why he spat at her. It could have been worse." Mimi answered that he could be right, but that life in mining is another world, an "open world." The man agreed: "Mines are special, they're like nowhere else." When I asked for an explanation Mimi answered that gold mines are like an ambivalent 'gate' ( $\mathrm{da}$ in Malinké), which can open up a world of opportunities ['chance,' harige] but also a world where one runs the risk of getting lost [tunun].

Women are highly visible in the gold mines. ${ }^{6}$ They work in groups lifting the bags of gravel and sometimes washing it (Dessertine 2016a). Artisanal gold mining offers them a financial opportunity as well as new mobility possibilities. Their mobility tends to be strongly regulated by the other villagers, and only a few women migrate to distant locations. As I have shown in a study on the mobility of the inhabitants of Guirilan (Dessertine 2013), these women were mostly first spouses and widows involved in the long-distance trade with Bamako (Mali). ${ }^{7}$ Their ability

\footnotetext{
Mali. More generally, see also D'Angelo on the exploitation on diamonds in Sierra Leone (2014, 2015) and Grätz on the "frontiers" of artisanal mining in West Africa (2004).

${ }^{5}$ Even though we were mostly speaking in Malinké, she said this in French: "un monde ouvert." "Some authors report them making up $50 \%$ of artisanal gold miners, as in Mali (Hentschel et al. 2003, 31).
}

${ }^{7}$ The inhabitants of this region practice polygyny. 
to migrate was closely linked to the duration of their marriage: as in other West African countries, the older a woman is the more her mobility is tolerated. Indeed, the more mobile are mostly first wives, the ones who are married for a longer time compared to the second, third, or fourth wife. However, in gold mining it makes no difference whether a woman is young or old, married or single. Thus, these spaces offer the opportunity to move for those who are not normally allowed to be mobile. This was made easier by their numerous movements between the mining sites and the village, the short duration of their stays in the camps, mostly only a few days, and the fact that the women I stayed with were mostly with working groups made up of inhabitants of Guirilan. In the mornings they did not go to the mining fields alone: they-and single women in particular-were always accompanied by their husbands, by their brothers or by older married women, even when they went to relieve themselves in the bush.

Despite this supervision of their mobility, and especially that of young and single women, staying at the gold mines allows them to act and behave differently. The description above on that point is explicit, because in the village of Guirilan women do not ordinarily sit and drink coffee with men. Some might discreetly ask the bartender for a little plastic bag of coffee, which they consume behind closed doors in their mud hut. In Faralako, women sat with men, and sometimes even with foreigners, at the café-bar. This is what make mines special, a place like nowhere else where actions that are normally forbidden to some actors are allowed, and where normally invisible behaviors are unveiled before everyone's eyes.

The particularity of the (inter)actions that arise in artisanal and small-scale mining spaces can be analyzed in terms of what Foucault calls heterotopia, spaces that are "counter-sites" "where 'normal' social behavior is not only contradicted but sometimes inverted" (Werthmann 2010, 131), sometimes even provoking long-lasting transformations (Dessertine 2016a). Indeed, these spaces are not only places where people can act in a way ordinarily seen as inappropriate; they are also places where individuals' status can change permanently, confirming its liminal nature. Mimi, for instance, dares to sit in the bar with men in Guirilan and has acquired a specific status due to her long years working 
in the mines. The villagers use certain expressions to describe her: "She's like a man"; "She's spent a long time in mining," etc. It is as if her long and repeated stays at the artisanal gold mines allow her to adopt a masculine behavior, which continues when she returns to the village. Mining spaces can thus assume a liminal role because of the relationships they allow and their dynamic form, which is always being recomposed and renegotiated by the multiple back-and-forth of migrants between the village and the mining sites. To put it differently, these spaces create the conditions of change because of their ephemeral and unstable setting.

However, the dynamism and the liminality of artisanal mining spaces are neither linear nor without conflict. In Mimi's explanation about the man who spat on a young girl with whom she was sitting in a cafébar because he was angry at the young woman's refusal of his sexual advances, what is interesting is the first comments of a bystander: "She's always walking, God knows where she's going." If mining spaces allow more mobility for women, there is a threshold that they should not overstep: a single woman walking alone without informing somebody with whom she shares her life in camp about it is condemned, as it raises suspicions that she is involved in a morally reprehensible behavior, such as having sexual intercourse with a stranger. Hence, while mining spaces provide opportunities to challenge gendered expectations, certain norms do not change. This shows that liminal spaces are intrinsically conflictual. They are at the core of processes of social change, giving new opportunities to subaltern actors which can have long-lasting consequences, as in Mimi's case. Indeed, they can, as Mimi put it, open the doors to another world, offering opportunities for contestation and transformation of the existing social order.

\section{A Doorway to a Modern World?}

It was a Sunday afternoon at Faralako in May 2011, and Lansiné and his fellow villagers from Guirilan had the day off. Lansiné was preparing tea while someone spread a big carpet on the ground under a tree for them to sit on. Only Lansiné sat on a plastic chair he had bought at the nearby market. A young man, stretching and relaxing his arms, said: "Life in mining is 
good!" (daman ka ni, literally "mines are soft, good"). Lansiné laughed and said "You're young - young people like mining." I asked him why he'd said that. He responded: "You can find everything in mining," and the young man continued "In mining I can do a lot of things I can't do in Guirilan. Look, first there's a market with lots of different products. I can buy beans, t-shirts, clothes, a cell phone-a lot of stuff we don't find in the village." Lansine started to explain, teasing the young man, that in mining he can spend his money directly without having to give part of it to his parents. The young man seemed a little embarrassed but did not contradict Lansiné. He started to justify himself: "Life for young people is not the same nowadays. There are a lot of expenses: good clothes, a phone, a motorbike; if you want to be respected, you must have things. Young people don't want to be excluded anymore." "Excluded from what?" I asked. "From the world. Mining can give us the chance to enter it." After a while two women came with food for everyone: beans, rice with peanut sauce, and skewers of liver. The young man looked at me and said "You see? Here it's like Europe. We have meat and different kinds of food. What do you say now?"8

Mining is described above as an opportunity to enter a world from which the young man had felt excluded when he was living in the village. This exclusion seems in part to depend on access to a variety of products. Miners feel that they can experience another world and leave their village life behind via new forms of consumption in the mining areas, whose markets offer a range of products that some young people associate with the European world, or at least with a form of inclusion in the global world. Mining spaces are not just liminal: they are doorways to the world, tacitly questioning the issue of modernity. Even if the young man did not express it clearly, his position toward the life in mining camps reminds of the dualism which James Ferguson analyzed in regard of the Zambian Copperbelt: "A persuasive and familiar dualism structured the way that most Copperbelt dwellers spoke about such matters. Contrasting styles of urban dress and comportment, workers said, reflected a fundamental difference between 'town ways' and 'village ways'. But what they described in one breath as a difference between

\footnotetext{
${ }^{8}$ This rhetorical question seemed to be a way of challenging me about my lifestyle and emphasizing the fact that life in mining can provide as much as in Europe.
} 
urban and rural might in the next become a contrast between 'modern' and 'traditional', 'European' versus 'African', or even 'educated' versus 'uneducated"' ([1959] 1999, 83).

As Ferguson points out, this dualist approach is further complicated by its ideological roots in modernization projects and their reinterpretations by the inhabitants of the region he studied. My informants, young and old, invoked the idea of a linear process from tradition to modernity, and mining sites seemed to be able to speed up this passage due to their role as liminal places that are neither village nor city. This liminality allows not only women to challenge gendered expectations but also young men to experiment with new forms of consumption and the performance of "modern" behavior. Like Sasha Newell's (2012) description of young men in Côte d'Ivoire who spent their meagre resources on branded clothing, technology, and food and drink, the young miners I met were eager to show off their access to and familiarity with the modern world, enabled by their new-found wealth.

The returns from mining, however, are not stable. While I heard many stories of miners who had made a fortune, triggering local mythologies of success, most of those whom I accompanied only made a little money every day. As one miner told me, "You never know what you're going to find-it's like a poker game." The imaginary of the game, and more generally of luck and gambling (D'Angelo 2015) is linked to specific understandings of money and its uses. Earnings from artisanal gold mining are perceived as "hot money" in contrast to the "cold money" earned from agriculture (see also Znoj 1998; Walsh 2003). Writing on sapphire mining in Madagascar, Walsh $(2003,302)$ links hot money to "daring consumption." He argues that while cold money is linked to continuity, hot money is associated with a temporality of disruption.

Similar associations apply in small-scale gold mines in Guinea. The vignette introducing this chapter showed the heterogenous temporalities of consumption in mining areas. The actions of the young men who were burning gas to show off their quick economic success and impress others were oriented toward the instant. Older miners who criticized these youngsters as irresponsible alluded to the importance of redistribution to establish the continuity of both existing social relations such as family ties, and financial returns, since redistribution supports the beneficiaries' 
subsistence and the miners' future success. Even if the tensions between these two forms of temporality-instantaneity and continuity-are a common cause of frictions between generations, the liminality of mining spaces brings them more closely into contact (Bergson [1889] 2013), and the clashes which this imbrication of relations to time provokes makes explicit dynamics of change which otherwise remain tacit. Below I show how the potential of change in mining camps is closely linked in this context to the ephemeral nature of artisanal and small-scale spaces of gold mining.

\section{Mines as Ephemeral Spaces?}

Mines are transformative, not just for those working and living there but also in their own right. Mining spaces appear and disappear, grow and decline as a result of various political, ecological, technological, and social factors. In 2015-2016, the military started systematically destroying mining camps, mostly by burning them. These interventions were officially presented as a way of securing the properties and fields of the industrial mining companies that had arrived in the region in large numbers after the Guinean government delivered many mining permits to them starting from 2014-2015 (Dessertine 2019).? The result, however, was not so much the disappearance of mining spaces as the mutation and relocation of artisanal and small-scale mining activities.

These changes were heightened by an increasing mechanization of mining and the spread of the new communication technologies. The introduction of metal detectors resulted in a more random mobility which allowed miners to spend only a day or two exploring a particular field before moving on to another. They slept sometimes in the bush, sometimes in the courtyard of a neighboring household or a hut rented from a local inhabitant, no longer establishing themselves in a particular camp by building a hut. This mobility has been facilitated by mobile

\footnotetext{
${ }^{9} \mathrm{~A}$ new Mining Code has already encouraged the liberalization of mining permits in 2011. However, because of the political instability at the beginning of Alpha Condés presidency between 2011 and 2013 and the Ebola epidemy between 2013 and 2015, the delivering of mining permits has accelerated only after 2015 .
} 
phones, allowing miners to exchange information on mining locations and to stay in contact with those left behind in the village. Women were mostly excluded from this mobility, either because their family did not allow it or because they chose to stay at home. Since the camps had been destroyed female miners were no longer able to resort to the protection of their own huts in the evenings, and concern for their safety had risen with the violent conflicts for the access of mining areas triggered by their militarization.

One consequence of these developments has been the masculinization of artisanal mining mobility and the feminization of their villages of origin, such as Guirilan. When I visited this village in 2017, most of the men had left to work in the mines. Some women found this a relief as they were no longer under the strict control of their fathers, brothers, or husbands, and could manage the profits from their gardening for themselves, giving them more financial autonomy. Moving between mining spaces became more masculine, opportunistic, and temporal. Cell phones, as I show below, play a central role in these new temporalities in mining spaces. However, this masculinization of mining mobility is not visible everywhere. In other villages in the Bouré region where men as well as women have been exploiting gold for centuries, another phenomenon can be observed: the rapid expansion of mining villages. Government restrictions on artisanal miners aimed to curb their mobility by allocating particular villages as mining sites and providing infrastructure such as buildings to facilitate mining and keep the miners in one place. Below I analyze these two a priori opposite trends: one leading to miners' hyper-mobility, and the other to the anchoring of mining spaces through micro-urbanization (Fig. 9.1).

\section{Hyper-Mobility: Mine(Rs) on the Move}

It has become something of a truism to say that the spread of cell phones has had a major impact on daily life and social relations all over the world. Focusing on Africa, Mirjam De Bruijn $(2008,18)$ calls for the study of the relationship between communication and societal change as mobile phones cause migrants on the margins to increasingly enter 


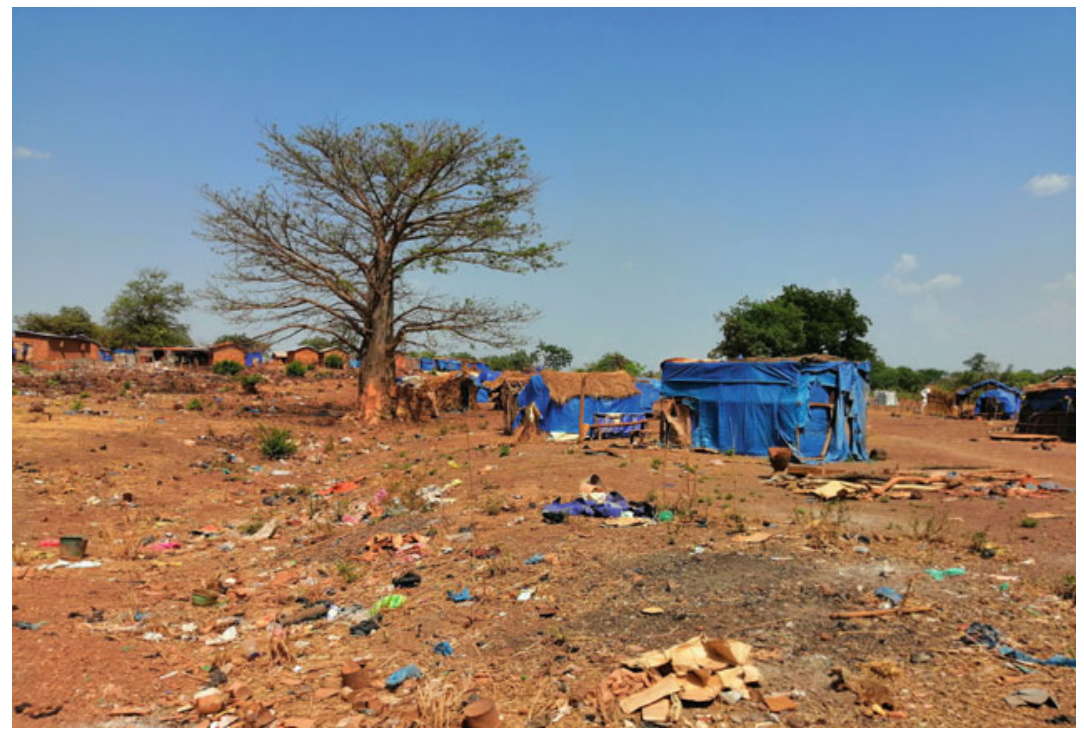

Fig. 9.1 Some shelters remaining in the mining town of Banjoula. New concrete buildings are visible in the background (Photo by the author)

"a life of 'in-betweenness' in which they constantly have to juggle with the faraway and the new environment close by, a situation that is experienced as coercive." This is also the case for miners, for whom mobile phones have become central to mediating between mining spaces, as well as between mining spaces and the village, in their context of increased mobility.

When I came back in Guinea for a six-month period of fieldwork in September 2012, I was struck by how many of the inhabitants of Guirilan had a cell phone. When I had first visited this village in 2006, no one owned a cell phone and many had asked me if I could bring them one. Yet by 2012 old models of mobile phones as well as smartphones were a common possession. They had become essential for the single men who went to work in the gold mines, as became clear to me when I accompanied Musa and two other young men to the gold mines in October and December that year. We did not know where to go at first, and decided to visit an acquaintance of Musa's in Siguiri. When we arrived at his place and started making tea, Musa received a phone call. It was Lamine calling him from Balato, a place 
near Siguiri known for its promising mining sites. Lamine proposed that we come and stay with him in a mud hut he had rented for a few nights from an inhabitant of Balato. We therefore packed our bags and went by bike to Balato. After three days, during which we found a few decigrams of gold, Musa's phone rang again. It was Madou, another native of Guirilan, who told him about a new field near Kourémalé at the Malian border. We decided to go and packed our bags again. After two days one of the young men of my group, Sékou, received a call from his mother, who wanted him to come home to help his younger brother with the farming as he had injured his foot. Sékou left for a week, during which we continued searching for a suitable place for prospecting, and then joined us again at Kourémale. He spoke to his mother and his younger brother on the phone every day to make sure that they were alright without him. Once, after talking to his mother, he was smiling contentedly. I asked him what was going on and he replied that he was so happy to be able to communicate with his family on a daily basis, because it meant that "We [his family and himself] are together (an be lé)."

This story shows that cell phones have the effect of making miners' mobility speedier and more volatile. Moreover, it shows that cell phones are more than just a communication tool; they are essential actors in their mobility, enabling them to maintain a form of presence at home despite their absence. First, they can be classically analyzed as a form of mediatized presence. By calling their families, the migrants ensure a form of presence and maintain an emotional and social continuity despite the geographical distance. Second, cell phones can be used with varying degrees of success to get migrants to return home: their presence is then no longer mediatized but immediate.

These observations are common in the literature, but what seems specific in this context is how presence and social recognition are closely linked there (Dessertine 2016b). The inhabitants of this region consider being present and visible necessary to perpetuate their social status. Physical visibility is fundamental to social recognition: old people are thus expected to be visible every day, sitting in their households' central courtyard; married men cannot leave their families for more than few weeks; single men must return home the day they become head of a household, etc. These obligations, even if their application may vary, produce 
different temporalities of absence depending on the individuals' age, sex, and status (Dessertine 2013). The use of cell phones seems to partly conciliate mining mobility and the social obligation to be present by giving rise to more opportunistic migration and round trips between the mining sites and the village. Hence cell phones offer new possibilities for mobility while at the same time, as in the case of Sékou, allowing forms of presence. However, even if cell phones are for some a means of maintaining good relations with the family, and more generally with the inhabitants of Guirilan, they also allow the family back in the village to pressure the migrant to fulfil her or his social obligations or return to the village. Of the 81 miners that I interviewed, 11 explicitly mentioned this ambivalence linked to cell phones and the family's ability to use them to exert pressure on them. Some miners, especially those who were not very successful at finding gold or who had spent their earnings in an ostentatious way, had partly cut their ties with their families because they did not want to return with nothing to give them.

The spread of cell phones combined with the spread of metal detectors has thus changed the miners' mobility patterns and social practices and prompted them to adopt forms of hyper-mobility. At the same time mining spaces are changing, becoming more ephemeral in certain areas and increasingly controlled by State authorities and industrial mining companies in others. Below I discuss what this means for the liminality of mining spaces, and whether they can still be seen as hotspots of change.

\section{Micro-Urbanization: Mining Territorialization}

While certain miners have become increasingly mobile, seeking to escape from the military operations to secure the claims of industrial companies on mining areas by becoming itinerants (Bolay 2016, 2017), others have become more fixed in particular mining spaces due to the increased regulation of mining practices through permits and stricter control of the mobility of miners. The military operations since 2015-2016 aimed to control mining, and mining companies have hired Guinean soldiers and officers to protect their sites. This has resulted in increased conflict over access to mining areas, with the result that the access to the sites has been drastically reduced, as shown in this conflictual social situation: 
In 2019, I went to Upper Guinea near the town of Lero, approximately 40 $\mathrm{km}$ from the Malian border. ${ }^{10}$ I was on my way back to town having stayed in a mining village for some days, when I saw people blocking the road with rocks. They were mainly women, who were crying and shouting at the police and at representatives of the local authorities. ${ }^{11}$ I stopped to ask what was going on. One of the women explained that they had been searching for gold in a field nearby and the police had come to evict them. One gendarme had pushed a woman, who had fallen and broken her arm, and beaten another. I looked at the two injured women, one of whom was unconscious with blood on her face and body. The gendarme who had done this worked on behalf of the major mining company in the area, Nordgold, and was in charge of expelling artisanal miners from company land. However, as the women repeated again and again, they had nothing left, no employment, and relied on prospecting for gold in this location to be able to feed their children. The soldiers and the representatives of local authorities who were present that day responded that this land now belonged to the mining company, which had a permit, and that they should respect the boundaries of the area that they could no longer enter legally. They gathered the women and took them to the jail in the military camp.

This example illustrates the emergence of new forms of mining in Guinea and how these are linked to the establishment of particular mining territories, legal regulations about private property and the use of State security forces to protect the boundaries of mining areas allotted to industrial companies. This territorial conception of space differs from that associated with artisanal and small-scale mining spaces: the first relies on national law and fixed boundaries, while the second is intrinsically changing with negotiable boundaries and falls within the scope of

\footnotetext{
${ }^{10}$ This fieldwork was part of a larger project on Lassa fever conducted with funding from the German Research Foundation (DFG FI 1781/1-1).

${ }^{11}$ As noted, Lero is one of the areas in this region where inhabitants have been prospecting for gold for centuries. This explains why, in contrast to Guirilan, women did not interrupt their mining activities after that the military operations hindered their mobility.
} 
customary law. While there would be a lot to say about the juxtaposition of these two conceptions of space, I focus here on how mining sites evolve as hotspots of change. ${ }^{12}$

The liminality of artisanal and small-scale mining spaces has been explained through their ephemeral nature which gives them their potential for change. How does the introduction of a territorial conception of space, linked to the temporality of permanence, redefine the modalities of social change? From the miners' point of view the introduction of this conception of space excludes them from land that they consider their property via customary law, and more generally from the benefits of owning gold. Camps are increasingly becoming extensions of villages, as according to the newest government regulations artisanal miners have to build a concrete building or at least a mud hut to be allowed to continue searching for gold on a given area. This anchoring of miners in space has led to the micro-urbanization of villages, some of which have tripled in size. In parallel, areas of artisanal exploitation are increasingly reduced by the expansion of legal industrial mining permits. The miners perceive this impossibility to move freely as a form of stagnation, reinforcing the argument that spaces are associated with specific perceptions of time. Moreover, it undermines the liminal character of the camps. Although it is too soon to speculate on how these processes of microurbanizations will evolve, it shows how the perception of time and with it, social change, is constructed by the forms that space takes.

${ }^{12}$ I have discussed the effects of the juxtaposition of mining spaces in more detail in previous publications: Dessertine (2016b, 2017, 2019). 


\section{Conclusion: Understanding Social Change Through the Analysis of Spaces}

This chapter began by considering social change from a spatial rather than the classical temporal perspective, without excluding a temporal perspective on the emergence, perpetuation, and disappearance of specific mining spaces. Mining spaces are constantly changing and being reconfigured, and this is why I first analyzed them as liminal and transformative as they allow for new kinds of behavior and practice. Within such liminal spaces men and women can experiment with behavior normally condemned in their villages, and can experience new forms of consumption normally associated with the "modern" world. These spaces are central to the changes in a migrant's status, not merely in economic terms but also, symbolically, as a representation of an "elsewhere." In gold mining, this "elsewhere," qualified as "Europe," "modernity" or "the West" becomes tangible. In this context, miners seem to move between places and at the same time between imaginary spaces. Indeed, the mobility of gold miners is analogical to them to a movement between new rural spaces and the "modern" world as they imagine it, introducing a time jump and an access to another temporality. In that sense, the spatial changes inherent in the mobility of mining activity and the changing character of mining spaces contain a temporal dimension, perceived by the miners as a social change.

Nevertheless, since the introduction of industrial mining permits and the systematization of military operations of expulsion hinders the mobility of miners, the feeling of stagnation it triggered has led to the waning of what could have been considered "hotspots of transition" (Dürrschmidt and Taylor 2007), meaning that the perception of space is also a perception of time, and that spaces shape how people see and feel social change. Thus, social change should no longer be understood according to a linear reading of time but as bound to spaces where diverse temporalities are imbricated (Bergson [1889] 2013) and where the individuals have the opportunity to perform and experience change. 


\section{Bibliography}

Bergson, Henri. [1889] 2013. Essai sur les données immédiates de la conscience. Paris: Flammarion.

Bolay, Matthieu. 2016. “'Il faut être là où l'or sort!' De l'itinérance temporaire au maintien d'un mode de vie mobile chez les orpailleurs de Haute Guinée." Stichproben: Wiener Zeitschrift für kritische Afrikastudien 16 (30): 111-35.

Bolay, Matthieu. 2017. "Gold Journeys: Expulsion-Induced Mobility and the Making of Artisanal Mining Spaces in West Africa: An Ethnography of Itinerant Labour at the Bottom of the Gold Supply Chain.” Ph.D. diss., University of Neuchâtel.

Bredeloup, Sylvie. 2014. Migrations d'aventures: Terrains africains. Paris: CTHSGéographie.

Cros, Michèle, and Mégret Quentin. 2009. "D’un idéal de virilité à l'autre? Du vengeur de sang au chercheur d'or en pays lobi Burkinabé.” Autrepart, 49: 137-54.

D’Angelo, Lorenzo. 2014. "Who owns the Diamonds? The Occult Economy of Diamond Mining in Sierra Leone." Africa 84 (20): 269-93.

D’Angelo, Lorenzo. 2015. “Diamond Mining Is a Chain': Luck, Blessing, and Gambling in Sierra Leone's Artisanal Mines.” Critical African Studies 7 (3): 243-61.

De Boeck, Filip. 1998. "Domesticating Diamonds and Dollars: Identity, Expenditure and Sharing in Southwestern Zaire (1984-1997).” Development and Change 29: 777-810.

De Bruijn, Mirjam. 2008. “'The Telephone has Grown Legs': Mobile Communication and Social Change in the Margins of African society." Inaugural Address, University of Leiden.

Dessertine, Anna. 2013. "Le lu ne meurt jamais: Mobilités des individus et pérennité de la résidence dans un village malinké de Guinée." Géocarrefour 88 (2): 131-38.

Dessertine, Anna. 2016a. "From Pickaxes to Metal Detectors: Gold Mining Mobility and Space in Upper Guinea, Guinea Conakry." The Extractive Industries and Societies 3: 435-41.

Dessertine, Anna. 2016b. "Présence imminentes: Mobilités et production de espaces dans un village malinké de Guinée." PhD diss., University of Paris Ouest-Nanterre La Défense.

Dessertine, Anna. 2017. "Fonder des limites: Appropriation des terres en contexte minier aurifere en haute Guinée (République de Guinée).” In 
(Re)Fonder: Les modalités du (re)commencement dans le temps et dans l'espace, edited by Philippe Gervais-Lambony, Frédéric Hurlet and Isabelle Rivoal, 217-28. Paris: Editions de Boccard.

Dessertine, Anna. 2019. "Une justice foncièrement autre? Pouvoir et foncier en contexte minier aurifere (Guinée)." Revue Internationale des Études du Développement 238: 141-64.

Dürrschmidt, Jörg and Graham Taylor. 2007. Globalization, Modernity \& Social Change: Hotspots of Transition. Basingstoke: Palgrave Macmillan.

Epstein, Arnold L. 1967. "Urbanization and Social Change in Africa." Current Anthropology 8 (4): 275-95.

Ferguson, James. 1999. Expectations of Modernity: Myths and Meanings of Urban Life on the Zambian Copperbelt. Berkeley, CA: University of California Press. Ferguson, James and Akhil Gupta. 1992. "Beyond 'Culture': Space, Identity, and the Politics of Difference." Cultural Anthropology 7 (1): 6-23.

Gluckman, Max. 1940a. "Analysis of a Social Situation in Modern Zululand: A. The Social Organisation in Modern Zululand.” Bantu Studies 14 (March): $1-29$.

Gluckman, Max. 1940b. "Analysis of a Social Situation in Modern Zululand: B. Social Change in Zululand." Bantu Studies 14 (June): 147-74.

Grätz, Tilo. 2004. "Les frontières de l'orpaillage en Afrique occidentale." Autrepart 30: 135-50.

Grätz, Tilo and Roland Marchal. 2003. "Les chercheurs d'or et la construction d'identités de migrants en Afrique de l'Ouest." Politique africaine 91: 15569.

Hentschel, Thomas, Félix Hruschka, and Michael Priester. 2003. "Artisanal and Small-Scale Mining: Challenges and Opportunities, Mining, Minerals and Sustainable Development.” IIED 73. http://pubs.iied.org/pdfs/9268IIED. pdf. Accessed July 17, 2019.

Huang, Zhen and Cheng Lu Wang. 2018. "Conspicuous Consumption in Emerging Market: The Case of Chinese Migrant Workers." Journal of Business Research 86 (2018): 366-73.

Mitchell, J. Clyde. 1961. "Social Change and the Stability of African Marriage in Northern Rhodesia." In Social change in Modern Africa, edited by Aidan Southall. London: Oxford University Press.

Newell, Sasha. 2012. The Modernity Bluff: Crime, Consumption, and Citizenship in Côte d'Ivoire. Chicago, IL: University of Chicago Press.

Niane, Djibril Tamsir and Ki-Zerbo Joseph. 1991. Histoire générale de l'Afrique: L'Afrique du XII ${ }^{e}$ au $X V I^{e}$ siècle. Paris: UNESCO. 
Panella, Cristiana. 2007. "L'éthique sociale du damansen." Cahiers d'études africaines 186. http://etudesafricaines.revues.org/7261. Accessed July 17, 2019.

Parry, Jonathan and Bloch Maurice. 1989. "Introduction: Money and the Morality of Exchange." In Money and the Morality of Exchange, edited by Jonathan Parry and Maurice Bloch, 1-32. Cambridge: Cambridge University Press.

Turner, Victor. 1974. "Liminal to Liminoïd, in Play, Flow, and Ritual: An Essay in Comparative Symbology." Rice Institute Pamphlet 60 (3): 53-92.

Van Gennep, Arnold. [1909] 1981. Les rites de passages. Paris: Éditions A. et J. Picard.

Walsh, Andrew. 2003. "'Hot Money' and Daring Consumption in a Northern Malagasy Sapphire-Mining Town.” American Ethnologist 30 (2): 290-305.

Werthmann, Katja. 2003. "Cowries, Gold and 'Bitter Money': Gold-Mining and Notions of Ill-Gotten Wealth in Burkina-Faso." Paideuma 49: 105-24. Werthmann, Katja. 2010. "Following the Hills': Gold Mining Camps as Heterotopias." In Translocality: The Study of Globalising Processes from a Southern Perspective, edited by Ulrike Freitag and Achim von Oppen, 111-32. Leiden: Brill.

Znoj, Heinzpeter. 1998. "Hot Money and War Debts: Transactional Regimes in Southwestern Sumatra." Comparative Studies in Society and History 40 (2): 193-222. 
Open Access This chapter is licensed under the terms of the Creative Commons Attribution 4.0 International License (http://creativecommons.org/ licenses/by/4.0/), which permits use, sharing, adaptation, distribution and reproduction in any medium or format, as long as you give appropriate credit to the original author(s) and the source, provide a link to the Creative Commons license and indicate if changes were made.

The images or other third party material in this chapter are included in the chapter's Creative Commons license, unless indicated otherwise in a credit line to the material. If material is not included in the chapter's Creative Commons license and your intended use is not permitted by statutory regulation or exceeds the permitted use, you will need to obtain permission directly from the copyright holder.

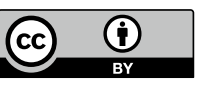

